\title{
Research on Tourism Management Professional Course System Reform
}

\author{
Xipeng Yang \\ Jilin Business and Technology College, Jilin, China
}

\begin{abstract}
In order to adapt to the development of tourism industry and tourism management professional characteristics, effectively solve the problems existing in the teaching. This paper take the tourism management major courses for clues, For tourism professional management curriculum present situation and the question to carry on the analysis, In tourist industry needed talents and tourism management specialized curriculum issues, Puts forward the tourism management specialized curriculum reform ideas and opinions. Hope tourism management professional in curriculum can better reflect the characteristics of tourism professional; highlight the time and the advanced.
\end{abstract}

KEYWORD: tourism management; curriculum; reform; structure optimization

\section{INTRODUCTION}

With the rapid development of social economy, the tourism industry will be vigorous development. High quality tourism services become China's modern tourism by the pursuit of the goal, how to achieve this goal, must grabbed from the quality of personnel engaged in tourism, But because of the tourism development is relatively slow, the corresponding education development is very slow, the teaching content and the social demands is out of line, So to achieve the goal, pay attention to personnel training mode, rich content of cultivation, it must to our country tourism education has thorough research, to adapt to the needs of the tourism industry to open course. To ensure that a large number of excellent tourism talents into tourism, so as to promote the healthy development of the tourism industry.

\section{HIGHER TOURISM MANAGEMENT CURRICULUM PRESENT SITUTATIONS}

Our country tourism education after 30 years of development, formed including secondary specialized schools and Colleges (students, training undergraduates, graduate students and doctoral students), relatively complete modern tourism education system for the rapid development of tourism industry provides a solid backup power. At present most of college tourism management specialty in the current course system are generally refer to the ministry of education in 1998 to common colleges and universities undergraduate professional directory to professional tourism management business training target set and design. In this regulation, training target regulations as "to develop a management, economy, folk culture, law and tourism professional knowledge, can in the various tourism administration department, tourism enterprise engaged in the management work of the senior specialized talents and have further to be engaged in the traveling teaching, scientific research potential research talent." China's tourism college curriculum study, the courses are divided into public compulsory, subject of general courses, professional courses, and elective classes four categories.

\subsection{Public compulsory}

Public compulsory is undergraduate stage every professional must be opened, train rounded all-round development of talent needed for general curriculum, its characteristic is subject and class with similar or identical characteristics, Public compulsory course is a cornerstone of university learning, is a better learning the basis of professional courses, Public compulsory course allows students to establish a scientific outlook on life and values, cultivate students' good personality and psychological quality, for the future work to ready, Public compulsory subject specific settings differ from colleges. Jilin business and technology college tourism 
management specialized compulsory course as show in table 1.

\subsection{The Disciplines of General Courses}

Subject curriculum is according to the professional the course with other disciplines relationship, opened several more important foundation course, designed to eliminate Long branch the drawbacks, trains the student to have the wide basic knowledge and comprehensive analysis of the basic ability according to the nature of discipline, General courses can include both natural science and Social Science two categories, tourism management belongs to the Social Sciences, including economics, history, the course of literature, higher mathematics. Jilin business and technology college tourism management major general class as shown in table 1 .

\subsection{Specialized Courses}

Professional required courses and elective courses are collectively referred to as the professional course, which is tourism management curriculum system the main component, Curriculum and class distribution for Tourism Management Major in college is very different. Professional required course is tourism management should learn and master the important course; required course is systematic and detailed to introduction tourism science and related theory, Interpretation and dissection of the relevant terms and concepts, to require that the student must master, and have relatively independent analysis and solving problem ability. Professional elective course is based on tourism management professional in the colleges and universities teachers open, each school open professional elective subjects different, elective course contents, Students according to their own interests to choose subjects, Most of the elective course class number is less, the teacher in the teaching, screening the main contents of the teaching. Jilin business and technology college tourism management specialty required courses and professional elective course such as table 1 .

Table 1 Jilin business and technology college tourism management specialty curriculum arrangement

\begin{tabular}{|l|l|}
\hline Course category & \\
\hline Public courses & $\begin{array}{l}\text { Principles of Marx, Mao Zedong thought, Deng Xiaoping Theory and "Three Represents " } \\
\text { important thought introduction, University computer foundation, sports, the ideological and } \\
\text { moral cultivation and legal basis }\end{array}$ \\
\hline Discipline curriculum & $\begin{array}{l}\text { Higher mathematics, introduction to management, financial management, western economics, } \\
\text { tourism law, tourism public relations, statistics }\end{array}$ \\
\hline Professional required courses & $\begin{array}{l}\text { Introduction to tourism, tourism geography, introduction to management, tourist psychology, } \\
\text { tourist accounting, hotel management, catering management, tourism marketing, tourism } \\
\text { economics }\end{array}$ \\
\hline Professional elective courses & $\begin{array}{l}\text { Introduction to the tourism industry, tourism education, tourism landscape appreciation, scenic } \\
\text { spot design, tourism environmental science, exhibition management, quality management }\end{array}$ \\
\hline
\end{tabular}

\section{THE PROBLEMS OF TOURISM MANAGEMENT CURRICULUM}

The curriculum system basically reflects the national Ministry education of tourism management professional requirements, but in the process of operation has some problems .

\subsection{Training Target Positioning}

On the training goal, the "tourism management professional knowledge "have different understanding. Tourism management involves multiple disciplines and fields, professional knowledge cover and contain everything, all colleges and universities to develop specific training goal difference. However, after all, tourism management is a subject. Tourism higher education should have a basic generic goal. Outstanding local tourism characteristics can't weaken the general goal of tourism management. Tourism management cannot do as natural science disciplines, have unified outline, the same goal, but the core of curriculum content should be similar or the same.

\subsection{Contents Duplication}

Tourism management is a burgeoning course, its discipline system is not mature, many subjects have overlapping knowledge, For example, take the aesthetic appreciation as an example, In the "tourism culture", "tourism aesthetics", "garden art" and so on the course are about, this will make students feel bored, and think tourism knowledge but also in this way, and there is no depth. Course content repetition not only includes professional internal knowledge repetition, also including different levels, the same course between the repeat, In higher tourism 
education college rises undergraduate graduate rise undergraduate this one phase, course repeated phenomenon is very serious.

\subsection{Practice Curriculum Relatively Weak}

Professional tourism management is a practical very strong professional, however, at present, our country tourism management specialized cultivate students not immediately involved in tourism industry, is because of the lack of practical ability, Most schools undergraduate course phase the course focuses on the theoretical learn, has neglected the practice skills training, Guide practice lesson very little, hotel practice lesson is about 2 to 3 weeks, graduation practice for half a year, the theoretical study for three and a half years of time, Only a handful of curriculum practice, caused the students practical ability is not strong, in the working process, from zero beginning, and other non this professional obtain employment personnel, and no protruding professional advantage.

\section{TOURISM MANAGEMENT PROFESSIONAL CURRICULUM STRUCTURE OPTIMIZATION}

\subsection{Opening Adapted to Travel Industry Course}

The curriculum and the needs of the industry consistent, tourism enterprise more need practical technical personnel to improve economic benefit. According to the tourism industry's own characteristic, it requires hire personnel can immediately into the post, and tourism management professional graduates are not adapted to the change of role, The main reason is in tourism management specialized course setting aspects didn't get good training. In the professional tourism management course setting, notice more practical knowledge.

\subsection{Discard the Dross and Select the Essential, Reduction Course Content Repeat}

Tourism professional the scope wide, want to learn things very much, therefore reduce too much repetition can make students have more time to learn other knowledge, The teacher speaking, can reduce the waste of time. College to regularly open course discussion, which content is door class explanation, these are to make specific instructions to avoid multiple teacher and teach a knowledge of the situation. Travel expertise covers broader, therefore in the limited class, teachers should choose more representatives of the contents talks, it is easier for students to understand and master .

\subsection{The Curriculum Procedure Reasonable}

The sequence of courses must be with course content logical sequence match, while also considering the students' psychological laws. First of all, professional basic course should be open in the professional direction before, and travel related specialized fundamental course should be more so. Secondly, in the general course, higher mathematics should be set up before the western economics, statistics, accounting and financial management, higher mathematics is learning these the foundation of this course subjects; Computers should also be provided in the tourism management information system. Can the practice through the entire four years of study, the course of the creation hotel, can let the professional tourism management students to the hotel practice, let them personally shake single, table operation.

\subsection{Optimizing Teaching Contents}

Professional tourism management belongs to the economic type and management category, therefore, the key points and difficulties more, in proportion of bigger, The student schoolwork burden is heavier, and it is difficult to distinguish between key and non-key, heavy schoolwork burden to make the students do not have much time to learn from. So lack of arouse the enthusiasm of students' study, therefore each course is divided into master content, skilled content and understanding content of the three types. Three kinds of teaching content ratio limit for $35 ; 25 ; 40$ or so. As shown in figure 1 .

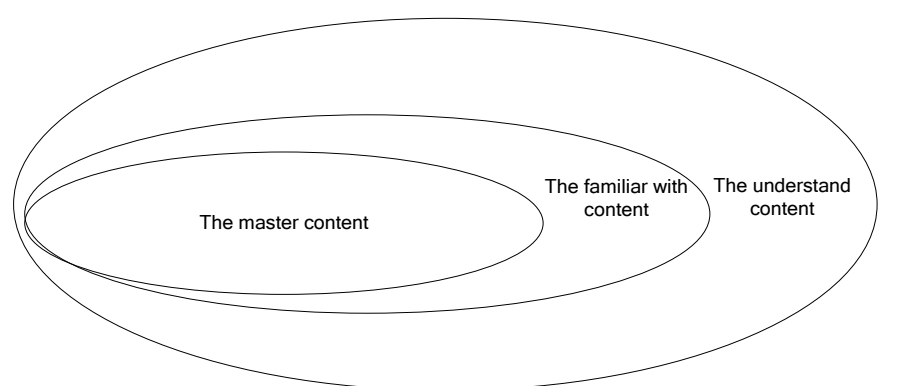

Fig. 1. Master content, skilled content; understand contents constitute relationship diagram

\section{TOURISM MANAGEMENT PROFESSIONAL CURRICULUM REFORM IDEAS}

\subsection{The Practice Teaching Reform}

Tourism management specialty is a strong practical and professional, requires that the student have a strong practical ability and solves problems, the ability to deal with emergencies. Practice is the application of theoretical knowledge, it is One of the important link to cultivate students' operation skill and service consciousness Schools should strengthen the tourism management specialty practice base construction and perfect practice base facilities and 
equipment, guarantee the smooth progress of practice teaching. Tourism College in hardware to establish and improve the professional tourism management practice base, simulation restaurant, front desk and guest room laboratory, so that students can learn basic essentials, avoid the work to start from the very beginning.

\subsection{The Teaching Methods and Reform of Means}

\subsubsection{The interactive heuristic teaching}

Want to develop students' image thinking ability and abstract thinking ability, will make students participate in the course, The heuristic teaching is such an instrument, it is based problem, take the student as the center, the discuss to as main teaching means, change the one-way teaching model, to explore their potential intelligence, is to play the enthusiasm of the students which is one of the most important methods. Interactive heuristic teaching is to make students and teachers face to face communication, in-depth research on teaching content, training students' creative thinking ability, But also is beneficial to the improvement of teachers' professional quality, through the discussion of students, carries on the analysis of the results, this will request the teacher in their spare time to learn more things, Not only to design problems, but also constantly supplement knowledge, such ability for interactive teaching.

5.2.2 The situation type teaching method

Situational teaching method refers to the use of the specific activity of the scene or to provide learning resources to arouse the learners' active learning interest, improves the efficiency of learning a kind of teaching method. Different with other teaching mode, and through the creation of set out authenticity and quasi the authenticity of the specific occasions the situation and the picture, To help students get knowledge into the vivid situation, enhance students' study interest, change the abstract teaching dull as ditch water situation. The creation of the scene more lively, vivid, accurate, students can understand the message, be moved by what one sees, active thinking, stimulate the express desire. In practical teaching, teachers through cosplay, multimedia, case teaching and application of scene teaching method.

\section{CONCLUSIONS}

This paper is mainly on the tourism management professional curriculum of the deficiencies, and put forward solutions. Due to geographical location, the school level is different, for professional tourism management curriculum is difficult to form a unified consensus. This paper for tourism management specialized curriculum the deficiency, and not have all put forward, just put forward some targeted problem, these are the focus of research in the future.

\section{REFERENCES}

[1] Li Wei (2004). Our higher tourism education curriculum reform to explore, Journal of Xinxiang teachers college, (9): 111-112.

[2] Li Guanghong (2008). The higher tourism professional curriculum to explore Based on the employment pressure,. journal of small and medium-sized enterprise management, science and technology, $11: 181$.

[3] Ni Weiqiu (2007). China's higher education of tourism talents cultivation mode of, business economics, 6: 109110.

[4] Xiao Ailian (2006). China's tourism education development, Journal of Hunan International Economics University, 2: 13-16.

[5] Wen Ping (2009). For tourism management undergraduate education the think, Education and vocational, 32:110-112.

[6] Zhang Huixia (2006). Higher tourism education reform strategy, Journal of Shanxi University of Finance and Economics, 9 (1): 19-21.

[7] Chen Xiaojing (2000). Higher tourism education reform, Journal of Yangzhou University, 4 (4): 72-75. 